\title{
WHAT GOOD IS PHILOSOPHY?
}

\author{
Ivona NovaK \\ University of Rijeka, Faculty of Humanities and Social Sciencies \\ Sveučilišna avenija 4, HR-51000 Rijeka, Croatia \\ E-mail address: ivona.novak88@gmail.com \\ IDA Mahmutefendić \\ University of Rijeka, Faculty of Humanities and Social Sciencies \\ Sveučilišna avenija 4, HR-51000 Rijeka, Croatia \\ E-mail address: ida.mahmutefendic@domzdravlja-pgz.hr
}

\begin{abstract}
The renowned status of philosophy and its significant historical tradition indicate there is a great value in the field and that it should be studied. Nonetheless, philosophers often find themselves being asked about the value of philosophy. On most occasions, the value in question is an instrumental value, concerned with the requirement for the study merely to yield some practical results. Another way of approaching the problem is to ask about the value of philosophy in itself. We call this an intrinsic value of something or value that is not a means for acquiring something else. In this paper, we will argue that the worth of philosophy lies in its ability to teach the human mind how to think. Our argument will account for both instrumental and intrinsic values of the study. We will also show that the argument holds regardless of what account about the nature of philosophy we adopt.

Keywords: Nature of philosophy, instrumental and intrinsic value, logic, critical thinking.

\section{INTRODUCTION}

In this paper, we try to examine the core of philosophy, and to do so we need to enter the area of metaphilosophy. We attempt to answer the following questions: Is there a value of philosophy in itself (i.e. is it intrinsically valuable), or its value manifests only in its adequate application (i.e. is it extrinsically valuable)? What is the value of philosophy in our lives? And finally, could philosophy have some value, not only in itself, as people who are professionally engaged in this discipline hold, but also extrinsically, for a broader range of citizens?

Before discussing the value of philosophy, we need to tackle the problem of what is philosophy. However, the question about the nature of this discipline is as complex as the question about its value. One way to answer the question is to divert the discussion about its nature to the etymological roots of the word
\end{abstract}


'philosophy'. The meaning of the word comes from the Greek philo meaning love and -sophos meaning wisdom (Klaić, 2007, p. 429). Philosophy is thus said to be love of wisdom. In ancient Greek, when things were easier for philosophy, philosophers were those who looked for fundamental truths about the world, life and human affairs. They sought answers to the basic questions.

If we were to claim that the nature of philosophy lies there, it seems that every person at some point in her life acts as a philosopher. However, there is an obvious and clear difference between ordinary wondering about the meaning of life and determination to comprehend the world, and being a professional philosopher. Since there is such difference between what we call philosophizing in everyday life and doing philosophy for a living, we need to account for it. We might begin by noticing that academic philosophers are trained in logic and their argumentation follows basic rules of reasoning. They are sensitive to logical fallacies and put large effort into avoiding them as well as into detecting them when they occur in the work of others. Apart from that, they are paid for what they do. Philosophizing is their passion, but also their job. They put all their time and work into discussion and argumentation. Frequently, papers and books they publish are difficult to comprehend to anyone outside the field because the problems they tackle are very specific and complex in nature.

Now, to go back to the question of our current interest. In their Introduction to Metaphilosophy, the most recent book that deals with metaphilsophical matters such as depicting the nature and the aim of philosophy, its utility and its place in the world, Overgaard, Gilbert and Burwood (2013) provide an overview of several positions of what philosophy ought to be. The question of what philosophy should be denotes a prescriptive aspect of the question about the nature of philosophy. This question might be reformulated by asking about the task or the aim of philosophy. In contrast, the question of what the existing philosophy is, denotes a descriptive aspect of the same question. Since answering the latter question requires only describing philosophical practice from ancient times up until this day, this section is concerned with a more challenging question, a prescriptive one.

As Overgaard et al. (2013, p. 26-44) noted, there have been numerous positions on what philosophy ought to be doing. When discussing the nature of philosophy with philosophers who lean towards the so called 'analytic' philosophy, the discussion usually boils down to the relationship between philosophy and empirical sciences. Be it as "part of science" (Overgaard et al., 2013, p. 26) in a Quinean sense or in a sense that experimental philosophers advocate, the danger of putting philosophy into the same basket with the empirical sciences lies in an inadequacy of accounting for the lack of progress in philosophy, the progress that sciences evidently do not lack. In the sea of ideas how exactly philosophy links to empirical sciences, there is a rather attractive idea of philosophy as "'midwife' and 'residue' of the sciences" (Overgaard et al., 2013, p. 30). According to this position, science can offer conclusive answers to some questions, but not to all of them. The questions that science cannot find a definite answer to, are left for philosophers to tackle. In this respect, philosophy actually generates new sciences. 
According to logical positivists, the nature of philosophy lies in analyzing scientific propositions. Another position that links philosophy with sciences suggests that philosophy contributes to human understanding. The task of sciences is to discover new knowledge and the task of philosophy is to utilize the understanding of that knowledge.

Several metaphilsophical positions seek the nature of philosophy independently of empirical sciences. Such practice is typical of continental philosophy. For instance, the Platonistic view suggests that philosophy, unlike empirical sciences that study what is accessible to sight, reveals the part of reality that goes beyond our sight. Phenomenologists believed that philosophy, namely phenomenology, was supposed to help us gain explicit understanding of our experience of the world. Other philosophers in the continental tradition held that philosophy was "a transcendental sort of inquiry" (Overgaard et al., 2013, p. 39) in a sense that it was concerned with how we gain knowledge, be it knowledge of ordinary things or scientific knowledge. Another position that originates from continental tradition asserts that philosophy ought to offer a world view, or "to capture what it is actually like to live a human life in the world" (Overgaard et al., 2013, p. 40). Finally, the quite unique position about what philosophy should be doing originates from Richard Rorty (1979). He advocates the view of philosophy that was not supposed to provide final answers to important questions, but rather "to keep the conversation going" (Rorty, 1979, p. 377).

Although many of the views on what philosophy ought to be doing seem quite appealing, one must be careful not to side with any before checking to what extent philosophers actually have been doing what is expected of them. In other words, there is no point in making prescriptions to philosophers if those prescriptions have nothing to do with the centuries old practice of philosophizing. Descriptive and prescriptive questions are two sides of the same coin. For that reason, after presenting each view on what philosophy ought to be doing, Overgaard et al. (2013) inspect to what degree each of these accounts is revisionist in relation to the practice of philosophizing. Since philosophers, unlike scientists or "other factgathering subjects" (Overgaard et al., 2013, p. 190) have never agreed upon what exactly their field of study should be, they have been preoccupied with a wide spectrum of, frequently opposing, inquires.

Taking that into consideration, we hold that the answer to the question of what philosophy ought to be lies in each view that has been provided. Philosophy has been and should be all that. We hold that, the conjoint feature of all philosophizing that has ever been done, and thus could be described as the nature of philosophy, is calling things into question accompanied by an effort to scratch beneath the surface of things, to analyze and problematize them. Among all the disciplines and fields of studying that exist, philosophy is the one that has never been afraid of asking the questions that have never been asked. It has never been afraid of entering the domains of thought no one has entered before. We will suggest that exactly this peculiar trait grasps both the instrumental and the intrinsic value of philosophy. 


\section{VALUES}

The discussion of intrinsic and extrinsic value stems from an exhaustive ontological debate on intrinsic and extrinsic properties. The idea is that objects have some properties intrinsically, by virtue of themselves, and others extrinsically, in relation to other things (Weatherson, \& Marshall, 2014). Without further going into this thorough discussion and leaving the controversy over what properties are actually intrinsic, we will accept that such a distinction roughly holds. Paradigmatic examples include solubility, mass, flammability and texture as intrinsic, and weight and volume as extrinsic or relational properties. A clear explanation of intrinsic and extrinsic properties was given by David Lewis:

A thing has its intrinsic properties by virtue of the way that thing itself, and nothing else, is. Not so for extrinsic properties, though a thing may well have these in virtue of the way some larger whole is (...). If something has an intrinsic property, then so does any perfect duplicate of that thing; whereas duplicates situated in different surroundings will differ in their extrinsic properties. (1983, p. 111-112)

In order to build our case for the importance of philosophy, we need to accept such distinction. The distinction between intrinsic and extrinsic value ${ }^{1}$ rests upon the idea that the aforementioned properties actually exist. G. E. Moore (1903, p. 18) asserted that there is an important difference between things that are good in themselves and as such possess intrinsic value, and things that are good only as a means to other things. Intrinsic value, which is the value that thing has in itself, or as such, "has traditionally been thought to lie at the heart of ethics" (Zimmerman, 2015). Since the very beginnings of Western philosophy, numerous candidates were suggested to be intrinsic goods. Classic examples include moral responsibility, moral justice, moral right and moral virtue and vice.

In his dialogue "Protagoras", Plato states that people condemn pleasure, not because they take it to be bad as such, but rather because of the bad consequences that pleasure has (Plato, 353d-353e). In the "Republic", Socrates maintains that an excessive pleasure and virtue do not go hand in hand (Plato, 402e), and in "Philebus" Philebus claims that pleasure is the highest good. However, Socrates argues against this and declares that pleasure is better when it goes along with intelligence (Plato, 60e). The postulate declaring that pleasure is intrinsically good, and pain is intrinsically bad, has had its implications over the centuries and many prominent names found their philosophical interest in that idea: Jeremy Bentham, Henry Sidgwick and John Stuart Mill (Zimmerman, 2015).

In addition to those few, other philosophers considered some other values (besides good and bad) to have intrinsic importance. One of the most extensive lists of intrinsic goods was given by William Frankena (1973, p. 87-88 as cited in Zimmermann, 2015): life, consciousness, activity, health and strength, pleasures

1 Christine Korsgaard (1996) distinguishes between four types of values instead of two: final, instrumental, intrinsic and extrinsic value. The metaphysical discussion about values is extensive, and since this paper discusses metaphilsophical issue, we will not enter it. 
and satisfactions of all or certain kinds, happiness, truth, knowledge and true opinions of various kinds, understanding, wisdom, beauty, harmony, aesthetic experience, love, friendship, cooperation, harmony and proportion in one's own life, power and experiences of achievement, self-expression, freedom, peace, security, good reputation, honor, and so on.

The question of whether something has its intrinsic value or not is an epistemological question, but it has been systematically discussed in moral philosophy. Unlike intrinsic, extrinsic goods are derivatively good (they have an instrumental value).Their value depends on some other value, to which it is related in some way. For instance, it is good to take a sleep and to eat and drink moderately because those activities lead to good health. Philosophers have found more interesting intrinsic good for philosophical debates. Obviously, this kind of good or value has been considered as a value of higher moral quality than the extrinsic one (Zimmerman, 2015).

\section{LOGIC AND CRITICAL THINKING}

Even though it has not always been the case, especially in the so called continental philosophical tradition, logic has generally managed to remain its status as an essential tool that philosophers use in their reasoning and argumentation. Today, studying logic is a core of studying philosophy at every philosophy department. Although there is some expected controversy over the definition of logic, it is generally defined as the study of the principles of correct reasoning or, the discipline of "modelling good reasoning" (Restall, 2006, p. 1). Standard definitions of logic define it as a philosophical discipline that deals with valid forms of thought and with the principles of consistent reasoning. The subjects of logic are the laws and regularities of reasoning. Logic does not aim at discovering the truth, but at investigating the form of thinking. Therefore, logic is a formal discipline that precedes and is the basis of other sciences (Kovač 2009; Petrović 2008). Every logician will agree with Greg Restall that "[s]tudying logic not only helps you to reason well, but it also helps you understand how reasoning works" (2006, p. 1).

According to standard definitions, critical thinking is "reasonable, reflective thinking that is focused on deciding what to believe or do" (Ennis, 1987, p. 10); "skillful, responsible thinking that is conducive to good judgment because it is sensitive to context, relies on criteria, and is self-correcting" (Lipman, 1995, p. 116) and "the propensity and skill to engage in an activity with reflective skepticism" (McPeck, 1981, p. 8). Principal traits of critical thinking, according to Wood (2002, p. 1), include using logic in our reasoning and being familiar with logical fallacies, being objective and open-minded, being sceptic and not accepting or dismissing anything before examining it, asking questions, being reflective and metacognitive in our reasoning as well as being careful and accurate. Following rules of logic and being cautious not to fall prey to logical fallacies is crucial to critical thinking.

Critical thinking is obviously instrumentally valuable. It leads to both extrinsically and intrinsically valuable things. To clarify, let us consider the 
following example. Money, evidently only has an instrumental value because it can help us get something that is said to have intrinsic value. For instance, money (at least in some cases) can insure health and health is intrinsically valuable. However, health is also instrumentally good or valuable because it helps us achieve some other values such as leading a normal life. As such, health is both intrinsically and instrumentally valuable. Likewise, critical thinking is instrumentally valuable because it can lead us to good reputation, experience of achievement, better understanding of the world and many other things that are said to be intrinsically valuable. It can also lead to some instrumental values such as good job, money or higher social class. Moreover, owing to previously described qualities of critical thinking, we hold that we are justified in accepting critical thinking as something that is also intrinsically valuable similarly as health, friendship, love or wisdom.

In the upcoming section, we will argue that, if we were to accept there is such thing as intrinsic value and that critical thinking is intrinsically valuable (or intrinsically good), then we ought to accept that philosophy is intrinsically valuable. We will also argue for the instrumental or extrinsic value of philosophy.

\section{BUILDING A CASE FOR PHILOSOPHY}

The question of the instrumental value of philosophy can be reformulated as the question of what good philosophy is, what the use of philosophy is or what philosophy is for. Overgaard et al. (2013, p. 192) refer to this value as the worth of "the products of philosophy". The question here, as Bertrand Russell (2013) famously puts it, is "what is the value of philosophy and why it ought to be studied" and "whether philosophy is anything better than innocent but useless trifling, hair-splitting distinctions, and controversies on matters concerning which knowledge is impossible". When compared to sciences, art or literature, the utility of the discipline is less evident. In other words, many people find it difficult to see how philosophy contributes to humanity. Unsurprisingly, professional philosophers are frequently asked about the point of philosophizing. As they are paid for what they do, people seek some explanation of why the work they do is worth being paid for. Where does the instrumental value of philosophy lie? Why is philosophy useful? Before moving on, an interesting point about the relation between instrumental and intrinsic value should be noted:

Is it that certain bits of knowledge are more fecund than others in the sense that they may generate more knowledge beyond themselves than other bits do, as knowledge of atomic particles, say, may be more productive than knowledge of the life history of butterflies? But butterflies may be more interesting than microscopic bits of matter, so might not knowledge of butterflies be more important, at least for most people? One might multiply competing criteria of importance here, and wonder whether there are any universal criteria. Perhaps it is a feature specific to our culture that the physical sciences take pride of place (...) (Overgaard et al., 2013, p. 190-191) 
Another question is whether philosophy has some intrinsic value? Could it go alongside other intrinsic goods from Frankena's (1973) list? Is there a distinctive trait of philosophy that makes it intrinsically worthy, that is, valuable for its own sake?

Let us first consider the question of intrinsic value of philosophy. Based on what has been established so far, this kind of value of the discipline can be accounted for. If one accepts the distinction between intrinsic and extrinsic values, and is ready to accept critical thinking as intrinsically good or something that is intrinsically valuable, then one should also accept philosophy as intrinsically valuable. We hold that philosophizing stimulates critical thinking. Moreover, a relationship between philosophy and critical thinking is reciprocal so critical thinking is also the basis for philosophizing. The more we philosophize and refine our reasoning, the better our power of critical thinking. It has been previously suggested that critical thinking is intrinsically valuable. Philosophy, as the stimulus for and, at the same time, the product of critical thinking is thus intrinsically valuable. We also hold that no other discipline or field of studying promotes critical thinking as philosophy does. It eventually teaches people how to think for themselves.

It has also been established that the core of philosophy is brining things into question. Be it by means of analysis like analytic philosophers frequently (although not exclusively) do or by presenting and discussing problems in a manner closer to a literary style, in any case, philosophy brings to the surface problems that no other discipline deals with. Moreover, logic, which is studied as essential part of philosophy, sharpens the human mind. It makes it sensitive to logical fallacies and to invalid argumentation. In other words, it teaches our mind how to think critically.

Russell (2013) noted a similar point by saying that "exclusively among the goods of the mind (...) the value of philosophy is to be found". However, Russell was advocator of the philosophy as "residue of the sciences" view (Overgaard et al., 2013, p. 30). He believed that philosophy aims primarily at knowledge (Overgaard et al., 2013), and in that sense, the view that we advocate here about the nature of philosophy diverges from his views. Claiming that philosophy aims primarily at knowledge or truth would exclude a large portion of philosophical opus from the field, and therefore, we adopt the view that philosophy is primarily concerned with questioning and problematizing, and that exactly these traits denote the nature of philosophy.

With intrinsic value in hand, it is easy to demonstrate that philosophy is also instrumentally valuable. Philosophizing, being intrinsically good, can lead to other things we cherish such as happier and more content lives, feeling of accomplishment and possibly to better position in society. As health or friendship are cherished for their own sake, but also for the good things they lead to, and as such, both intrinsically and instrumentally valuable, philosophy is valued in a similar manner. Even if one refuses to accept that philosophy can lead to other good things as health can, owing to its peculiar relation to critical thinking, if nothing else, philosophy leads to critical thinking. In that sense, it has at least some instrumental value.

Finally, one caveat should be noted. Even though logic has been included as a fundamental part of philosophy in every philosophy department, one might think 
of myriad philosophers that have not followed the rules of logic in their works, and whose expression of thoughts and ideas is closer to a literary work than to a strictly philosophical one. This has been especially the case with continental philosophers, phenomenologists and existentialists particularly. ${ }^{2}$ Two replies to such objection could be made. First, even in cases when philosophers did not pay much attention to logic as far as the expression of their views goes, their ideas could be reformulated as to have the form of valid arguments. Second, the core of critical thinking lies in questioning the current state of affairs, finding what is wrong with it and seeking places for improvement. Everyone will accept that, if anything, questioning and criticizing is what philosophers do.

\section{CONCLUSION}

In this paper, we have tried to demonstrate the value of philosophy, both the intrinsic and instrumental one, regardless of what account about the nature of the philosophy we adopt. Moreover, we have tried to reach the matter of the complexity of nature and value of philosophy. We noted that it is impossible to provide the answers to these questions without making a distinction between philosophy and (empirical) sciences, as well as between philosophy in its early ages, when, assumed, things were easier for philosophy, and nowadays.

As it has been demonstrated, there are two aspects of the question about the nature of philosophy: the prescriptive and descriptive one. The question of what the existing philosophy is, denotes a descriptive aspect of the question about the nature of philosophy. However, in this paper we discuss a prescriptive question, as it is a more challenging one.

We have presented several views on what philosophy ought to be. In analytic tradition, philosophy is thought to generate new sciences, contribute to human understanding, utilize the understanding of that knowledge, and, according to logical positivists, analyze the scientific propositions. A differing view comes from the Platonists who hold that philosophy ought to reveal the part of reality that goes beyond our sight. Few continental philosophers put forward the question of "what it is actually like to live a human life in the world" (Overgaard et al., 2013, p. 40). Richard Rorty held that the aim of philosophy is not to provide answers to some basic questions, but "to keep the conversation going" (Rorty, 1979, p. 377).

Furthermore, in this paper, we have demonstrated the enormous role of logic and critical thinking in philosophy. From the ontological distinction between intrinsic and extrinsic properties, it follows that some things have their intrinsic value, while others are valuable only extrinsically. Critical thinking is one of the things with both extrinsic and intrinsic value. We argued that the core of philosophical examination is precisely a development of critical thinking, which has both extrinsic (instrumental), and intrinsic value. Since no other discipline promotes the development of critical thinking as philosophy does (or, in other

2 Think of Georg Wilhelm Friedrich Hegel, Friedrich Nietzsche, Arthur Schopenhauer or Martin Heidegger for instance. 
words, philosophizing entails critical thinking), philosophy has both intrinsic and extrinsic value.

For that reason we hold that philosophy should be studied, it should continue to seek its place in the world; be it side by side with empirical sciences, a discipline that seeks the answers to the big questions, a critique of the social affairs or something else. Philosophical works that have been written so far should be read and new works should be written. It should continue asking the important questions, seeking irregularities where everyone else sees regularities, and most importantly, it should continue refining the human mind as to make it sensitive to logical fallacies and better in its reasoning.

\section{REFERENCES}

Ennis, R. H. (1987). A taxonomy of critical thinking dispositions and abilities. In: J. Baron, \& R. Sternberg (Eds.), Teaching thinking skills: Theory and practice (pp. 9-26). New York: W. H. Freeman.

Frankena, W. K. (1973). Ethics (Second ed.). Englewood Cliffs: Prentice Hall.

Klaić, B. (2007). Rječnik stranih riječi [Dictionary of foreign words]. Zagreb: Školska knjiga.

Korsgaard, C. M. (1996). Two Distinctions in Goodness. In: C. M. Korsgaard, Creating the Kingdom of Ends (pp. 249-74). Cambridge: Cambridge University Press.

Kovač, S. (2009). Logika [Logic]. Zagreb: Hrvatska sveučilišna naklada.

Lewis, D. (1983). Extrinsic Properties. Philosophical Studies, (44), 197-200.

Lipman, M. (1995). Thinking in Education. Cambridge: Cambridge University Press.

McPeck, J. E. (1981). Critical Thinking and Education. New York: St. Martin's Press.

Moore, G. E. (1903). Principia Ethica. Cambridge: Cambridge University Press.

Overgaard, S., Gilbert, P., \& Burwood, S. (2013). An Introduction to Metaphilosophy. New York: Cambridge University Press.

Petrović, G. (2008). Logika: udžbenik za 3. razred gimnazije [Logic: a textbook for the 3rd grade of gymnasium]. Zagreb: Školska knjiga.

Plato. (n.d.). Philebus. Retrieved November 4, 2015, from http:/ / www.perseus.tufts.edu/hopper/text? doc=Perseus\%3Atext\%3A1999.01.0174\%3Atext\%3DPhileb.\%3Asection\%3D60e.

Plato. (n.d.). Protagoras. Retrieved November 4, 2015, from http://www.perseus.tufts.edu/hopper/ text?doc=Perseus\%3Atext\%3A1999.01.0178\%3Atext\%3DProt.\%3Asection\%3D353d.

Plato. (n.d.). Republic. Retrieved November 4, 2015, from http://www.perseus.tufts.edu/hopper/ text?doc=Perseus\%3Atext\%3A1999.01.0168\%3Abook\%3D3\%3Asection\%3D402e.

Restall, G. (2006). Logic: An Introduction. London and New york: Routledge, Taylor \& Francis Group.

Rorty, R. (1979). Philosophy and the Mirror of Nature. Princeton: Princeton University Press.

Russell, B. (2013). The Problems of Philosophy. Retrieved August 12, 2015, from http:/ / www.gutenberg. org/files/5827/5827-h/5827-h.html.

Weatherson, B., \& Marshall, D. (2014). Intrinsic vs. Extrinsic Properties. Retrieved August 8, 2015, from http://plato.stanford.edu/archives/fall2014/entries/intrinsic-extrinsic/.

Wood, R. (2002). Critical Thinking. Retrieved August 12, 2015, from http://www.robinwood.com/ Democracy/GeneralEssays/CriticalThinking.pdf.

Zimmerman, M. J. (2015). Intrinsic vs. Extrinsic Value. Retrieved August 8, 2015 from http://plato. stanford.edu/archives/spr2015/entries/value-intrinsic-extrinsic/. 